\title{
Variation and Heritability Estimates for Antioxidant Activity, Total Phenolic Content, and Anthocyanin Content in Blueberry Progenies
}

\author{
Ann Marie Connor, James J. Luby, and Cindy B.S. Tong \\ Department of Horticultural Science, 1970 Folwell Ave., University of Minnesota, St. Paul, MN 55108
}

AdDitional INDEX WORDs. Vaccinium sp., blueberry breeding

\begin{abstract}
AвSTRACT. Narrow-sense heritability and among-family and within-family variance components were estimated for antioxidant activity (AA), total phenolic content (TPH), and anthocyanin content (ACY) in blueberry (Vaccinium L. Sp.) fruit. AA, TPH, and ACY were determined in the parents and in 10 offspring from each of 20 random crosses for each of 2 years at Becker, Minn. Offspring-midparent regression analysis provided combined-year heritability estimates of $0.43 \pm 0.09(P$ $\leq 0.0001)$ for $\mathrm{AA}, 0.46 \pm 0.11(P \leq 0.0001)$ for $\mathrm{TPH}$, and $0.56 \pm 0.10(P \leq 0.0001)$ for $\mathrm{ACY}$. Analyses of variance delineated variation among and within families for $\mathrm{AA}, \mathrm{TPH}$, and $\mathrm{ACY}(P \leq 0.001)$. Year-to-year variation in the means for all offspring genotypes was not significant for AA or TPH, but there were changes in rank between years for families and for offspring within families for these traits. Year-to-year variation in the mean for all offspring genotypes was significant for ACY, but rank changes were observed only among offspring within families, not among families. In total, 18 of 200 offspring from 7 of the 20 crosses were transgressive segregants for AA, exceeding the higher parent of the cross by at least two SDS. Estimates of variance components showed that variation among families accounted for $24 \%$ to $27 \%$ of total variance for the three traits. However, variation within families was greater than that among families, accounting for $38 \%$ to $56 \%$ of total variance for the three traits. These results suggest that increasing antioxidant activity in blueberry through breeding is feasible, and that the breeding strategies utilized should exploit the large within-family variation that exists.
\end{abstract}

Diets high in fruit and vegetables are associated with lower risk for a number of serious health disorders, including coronary heart disease and some forms of stroke (Joshipura et al., 1999; Liu et al., 2000; Ness and Powles, 1997), and certain types of cancer(Steinmetz and Potter, 1996; Zhang et al., 2000). The agents responsible for these various protective effects are not clearly defined but are proposed to include antioxidant compounds (including flavonoids, other phenolic compounds, and specific vitamins such as $\mathrm{C}$ or E), carotenoids, fiber, folate, potassium, selenium, phytoestrogens, and others. Several studies have noted specifically the inverse association between dietary flavonoids and stroke (Keli et al., 1996), lung cancer (Knektet al., 1997), and coronary heart disease (Hertog et al., 1993, 1997; Knekt et al., 1996).

Blueberries (Vaccinium sp.) are a good source of phenolic acids, principally chlorogenic acid, and of flavonoids, because of their high anthocyanin content. They are among the fresh fruit sources with the highest antioxidant activity (AA) (Kalt et al., 1999; Prior et al., 1998). Studies in our laboratory demonstrated significant variation in AA among blueberry genotypes (Connor, 2001), and Ehlenfeldt and Prior (2001) demonstrated a greater than 6-fold range in AA as determined by oxygen radical absorbance capacity (ORAC) among 87 highbush blueberry cultivars. Thus, the potential exists to breed blueberries with higher antioxidant activity. Choosing the most effective breeding strategies for this goal, however, can be facilitated by estimates of the heritability of the trait and the variance components. In this study we estimated repeatability, narrow-sense heritability, and among-family and within-family variance components for AA, total phenolic content (TPH), and anthocyanin content (ACY) using a series of crosses representing northern highbush (V. corymbosum L.), lowbush (V. angustifolium Ait.), and half-high (V.corymbosum $\times$ V. angustifolium derivatives) blueberries.

Received for publication 29 May 2001. Accepted for publication 11 Sept. 2001. We thank Frank Martin and Nancy Ehlke for statistical advice.

\section{Materials and Methods}

Plants. Ten healthy, fruiting full-sib offspring were chosen from each of 20 blueberry progenies available in the breeding program at the University of Minnesota, St. Paul. Full-sib progenies were randomly chosen without knowledge of the AA, TPH, or ACY of either the parents or the offspring. A total of 28 parental genotypes were used, with each represented in one to three crosses. The parents represented V. corymbosum, V. angustifolium, and derivatives of these species (Table 1). All offspring and parental plants were grown at the Sand Plain Research Farm in Becker, Minn., on a Hubbard loamy sand (sandy, mixed, Udorthentic Haploboroll) with 2\% to 3\% organic matter and soil $\mathrm{pH}$ of 5.5. The plants ranged in age from 7 to 23 years.

Fruit. Berries were harvested in 1998 and 1999. About $100 \mathrm{~g}$ ripe fruit was harvested from each of the parental and offspring plants when $40 \%$ to $70 \%$ of the fruit on the bush were ripe. Fruit were held in polyethylene bags on ice in coolers until frozen at $-80^{\circ} \mathrm{C}$ the same day. Berries in each genotype sample were weighed and counted before freezing.

Extractions. Extractions were performed under reduced light conditions. Extracts for all assays were prepared using acidified methanol $(0.1 \% \mathrm{HCl})$. This solvent maximizes extraction of anthocyanins (Harborne, 1967), and studies in our lab (data not presented) demonstrated that acidified methanol was superior to methanol-formic acid-water (Gao and Mazza, 1994) for recovery of anthocyanins. Preliminary studies (data not presented) demonstrated no substantial difference in total phenolic content between extracts prepared in acidified methanol and those prepared in $80 \%$ ethanol (Coseteng and Lee, 1987). About $10 \mathrm{~g}$ of frozen berries were weighed and counted and partially thawed at $-20^{\circ} \mathrm{C}$. They were homogenized for $2 \mathrm{~min}$ in acidified $(0.1 \% \mathrm{HCl})$ methanol, $1: 1 \mathrm{w} / \mathrm{v}$, using a Polytron (Kinematica, Luzern, Switzerland) homogenizer. A second identical volume of acidified methanol was used to rinse the homogenizer probe and then combined with the homogenate. The homogenate was al- 
Table 1. Species ancestry of parental genotypes used to produce 20 blueberry (Vaccinium sp.) families for analyses of antioxidant activity, total phenolic content and anthocyanin content, and the family number(s) in which each genotype was used as maternal $(\mathrm{M})$ or paternal $(\mathrm{P})$ parent.

\begin{tabular}{|c|c|c|c|}
\hline Genotype & V. corymbosum ${ }^{2}$ & V. angustifolium $^{\mathrm{z}}$ & $\begin{array}{c}\text { Family no.(s) } \\
\text { and parental use }\end{array}$ \\
\hline Bluegold & $\mathrm{X}$ & $\mathrm{X}$ & 17-M, 18-M \\
\hline Bluetta & $X$ & $\mathrm{X}$ & 6-M, 7-M \\
\hline Bounty & $X$ & $\mathrm{X}$ & 14-P, 15-P \\
\hline B1-1 & $X$ & & 2-P \\
\hline B6 & $X$ & & $8-\mathrm{M}$ \\
\hline B10 & $X$ & & 9-M \\
\hline B11 & $X$ & & 5-P \\
\hline Chippewa & $X$ & $X$ & 19-M, 20-P \\
\hline GR 2 & $X$ & $X$ & 9-P \\
\hline GR V.a. & & $\mathrm{X}$ & 2-M, 3-M \\
\hline MN61 & $X$ & $\mathrm{X}$ & 1-P, 8-P \\
\hline MN84 & $\mathrm{X}$ & $\mathrm{X}$ & 4-M, 5-M \\
\hline MN449 & $X$ & $X$ & 15-M, 16-M \\
\hline MN452 & $X$ & $\mathrm{X}$ & 13-P \\
\hline MN455 & $X$ & $X$ & $10-\mathrm{M}$ \\
\hline MN496 & $X$ & $\mathrm{X}$ & 12-M, 13-M, 19-P \\
\hline MN497 & $X$ & $\mathrm{X}$ & 11-M, 14-M \\
\hline Nelson & $X$ & & 18-P \\
\hline Northblue & $X$ & $\mathrm{X}$ & 16-P, 17-P \\
\hline Northcountry & $X$ & $\mathrm{X}$ & 3-P \\
\hline Northland & $X$ & $\mathrm{X}$ & $10-\mathrm{P}$ \\
\hline Northsky & $X$ & $\mathrm{X}$ & 6-P \\
\hline N70145 & & $\mathrm{X}$ & $12-\mathrm{P}$ \\
\hline N70218 & $X$ & & 4-P \\
\hline N70249 & & $\mathrm{X}$ & $1-\mathrm{M}$ \\
\hline Patriot & $X$ & & $11-\mathrm{P}$ \\
\hline Polaris & $X$ & $X$ & $20-\mathrm{M}$ \\
\hline R2P4 & $X$ & $X$ & 7-P \\
\hline
\end{tabular}

$\overline{{ }^{\mathrm{z}} \text { Genotypes representing interspecies hybrids vary in the proportion of }}$ each species that contributes to their genetic background.

lowed to stand on ice for a minimum of $20 \mathrm{~min}$ and then filtered by gravity through $11 \mathrm{~mm}$ filter paper. The residue was mixed with a third identical volume of acidified methanol and refiltered. Filtrates were combined and standardized to $30 \mathrm{~mL}$. An 8-mL aliquot of the extract was stored at $-80{ }^{\circ} \mathrm{C}$ until assayed. Three extracts were prepared for each offspring and parental genotype and duplicate determinations of AA, TPH, and ACY were made on each extract.

AA ASSAY. The AA assay measures the inhibition of peroxyl radical-induced oxidation of methyl linoleate produced by the addition of berry extract. It is based on the methods used by Barclay et al. (1984) to study oxidation of linoleic acid in heterogeneous systems using various initiators and inhibitors of oxidation, and by Fuhrman et al. (1995) to study the susceptibility of human plasma and low-density lipoprotein to lipid peroxidation following consumption of red wine. In our study, the aqueous peroxyl radical generator 2,2'-azobis amidinopropane dihydrochloride (AAPH; Wako Chem., Richmond, Va.) $(10 \mu \mathrm{m}$ final concentration) was used to induce oxidation of a linoleic acid methyl ester (Sigma Chem., St Louis) $\left(3.1 \mathrm{mg} \cdot \mathrm{mL}^{-1}\right.$ final concentration) emulsion prepared in $0.1 \mathrm{M}$ sodium phosphate buffer $(\mathrm{pH} 7.0)$ containing Tween $20(1.0 \% \mathrm{w} / \mathrm{v})$. Antioxidant activity was determined by measuring inhibition of lipid oxidation achieved by addition of diluted blueberry extract to the emulsion (final extract dilution 1:800; total reaction volume of $1 \mathrm{~mL}$ ). The oxidation reaction was carried out at $37^{\circ} \mathrm{C}$ for 130 min in a shaking water bath (model 25; Precision Scientific, Chicago) at $100 \mathrm{rpm}$, and terminated by placing the reaction tubes on ice. Oxidation products were detected as malondialdehyde equivalents in a thiobarbituric acid reaction based on the method by Lee et al. (1992) and measured at $535 \mathrm{~nm}$ on a spectrophotometer (DU-50; Beckman Instruments, Fullerton, Calif.). Color interference by anthocyanins in the diluted extracts was adjusted for, if necessary, with a color blank, substituting sodium phosphate buffer for the methyl linoleate suspension. Appropriate controls to assess baseline oxidation and the effect of methanol in the diluted extracts were included. An antioxidant standard curve was prepared with each assay, substituting the watersoluble vitamin E analogue Trolox (Aldrich Chem., Milwaukee, Wis.) for the blueberry extract at appropriate dilutions. The standard curve was linear between 0 and $30 \mu \mathrm{m}$ Trolox equivalents (TE) (final concentration). Results are expressed as $\mu \mathrm{mol} \mathrm{TE} / \mathrm{g}$ fresh fruit.

Total PhENOLIC CONTENT. A Folin Ciocalteu-based method, as applied by Coseteng and Lee (1987) was used, with an incubation time of $90 \mathrm{~min}$ for color development. Chlorogenic acid (Sigma Chem.) was used as a standard, and the standard curve was linear between 0 and $60 \mathrm{mg} \cdot \mathrm{mL}^{-1}$. Results are expressed as $\mathrm{mg}$ chlorogenic acid equivalents $/ 100 \mathrm{~g}$ fresh fruit, which, under the conditions of this assay, were determined to be $\approx 1.8 \times$ gallic acid equivalents.

ANTHOCYANIn CONTENT. Total anthocyanin content was determined by measuring spectrophotometric absorbance at $530 \mathrm{~nm}$, following dilution $(1: 99, \mathrm{v} / \mathrm{v})$ of the extract with acidified methanol to achieve absorbance readings between 0.200 and 1.000. Results are expressed as mg cyanidin 3-glucoside equivalents/ $100 \mathrm{~g}$ fresh fruit using a molar extinction coefficient of 29,600.

Statistical analyses. Narrow-sense heritability $\left(h^{2}\right)$ estimates were obtained using offspring $(\mathrm{O})$-midparent $(\mathrm{MP})$ regression, where $h^{2}=b=\operatorname{cov}(\mathrm{O}, \mathrm{MP}) / \operatorname{cov}(\mathrm{MP})$ (Falconer and Mackay, 1996). Analyses of variance (ANOVA) using either family mean and year or individual offspring genotype mean and year as random effects were used to calculate repeatability on family-mean basis: $\sigma_{\text {family }}^{2} /\left\{\sigma_{\text {family }}^{2}+\left(\sigma_{\text {family } \times \text { year }}^{2} / 2\right)\right\}$; or genotype mean basis: $\sigma_{\text {genotype }}^{2} /\left\{\sigma_{\text {genotype }}^{2}+\left(\sigma_{\text {genotype } \times \text { year }}^{2} / 2\right)\right\}$, respectively. To determine variance components, ANOVA were performed with offspring genotype, year, and extract as random effects, with extract nested within genotype. For all analyses, $P=0.05$. Analyses were performed using SPSS for Windows, version 8.0 (SPSS, Inc., Chicago), or MacAnova for Windows, version 4.04 (Dept. of Applied Statistics, Univ. of Minnesota, Minneapolis). Satterthwaite's (1946) approximation was used to calculate error terms where appropriate.

\section{Results}

Values for the parents of the 20 families and the mean and range in values among the offspring in each family for $\mathrm{AA}, \mathrm{TPH}$, and ACY in each year are listed in Tables 2, 3, and 4, respectively. For many crosses, both parents demonstrated moderate AA, but in five crosses the parents were quite divergent. Some of the parental genotypes showed considerable change in AA between 1998 and 1999, but the mean among all parental genotypes did not change substantially for AA between the 2 years: TE, 31.9 and $31.8 \mu \mathrm{mol} \cdot \mathrm{g}^{-1}$ fresh fruit in 1998 and 1999 , respectively. The mean value for TPH and ACY among all parental genotypes reflected a similar pattern, with little change between years: 526 and $538 \mathrm{mg} / 100 \mathrm{~g}$ fresh fruit in 1998 and 1999, respectively, for 
TPH; and 201 and $208 \mathrm{mg} / 100 \mathrm{~g}$ fresh fruit in 1998 and 1999, respectively, for ACY. The within-family range for AA varied from $10.9 \mu \mathrm{mol} \cdot \mathrm{g}^{-1}$ (35.1 to $24.2 \mu \mathrm{mol} \cdot \mathrm{g}^{-1}$ for MN496 $\times$ N70145) to $31.7 \mu \mathrm{mol} \cdot \mathrm{g}^{-1}$ ( 60.5 to $28.8 \mu \mathrm{mol} \cdot \mathrm{g}^{-1}$ for 'Bluegold' $\mathrm{x}$ 'Nelson') in 1998, a 2.9-fold variation; and from $11.1 \mu \mathrm{mol} \cdot \mathrm{g}^{-1}$ (37.5 to 26.4 $\mu \mathrm{mol} \cdot \mathrm{g}^{-1}$ for MN455 x 'Northland') to $38.6 \mu \mathrm{mol} \cdot \mathrm{g}^{-1}$ (63.8 to 25.2 $\mu \mathrm{mol} \cdot \mathrm{g}^{-1}$ for 'Bluegold' $\mathrm{x}$ 'Northblue') in 1999, a 3.5-fold variation. The variation in within-family range for TPH was of similar magnitude as that for AA in 1998 (2.6-fold), but was considerably greater in 1999 (4.5-fold). For ACY, variation in within-family range was greater than that observed for AA in 1998 (3.5-fold) and in 1999 (5.1-fold). Correlations among the variables on a genotype mean basis for the 200 offspring over 2 years were $r=$ 0.91 for AA and TPH, $r=0.70$ for AA and ACY, and $r=0.87$ for TPH and ACY $(P \leq 0.01$ for all $)$.

The expected mean squares for each source of variation included in the ANOVA for family AA, TPH, and ACY are presented in Table 5. The ANOVA are shown in Table 6 (top) and the contributions of each component to the total variance (bottom). For all three traits, among-family variation and withinfamily variation were highly significant. For AA and TPH, the mean performance of all 200 offspring did not change between

Table 2. Antioxidant activity (TE, $\mu \mathrm{mol} \cdot \mathrm{g}^{-1}$ fresh fruit) of maternal (M) and paternal (P) parents with mean and range among $10 \mathrm{offspring}$, in 20 blueberry (Vaccinium sp.) families (listed by number as indicated in Table 1) in 1998 and 1999.

\begin{tabular}{|c|c|c|c|c|}
\hline \multirow[b]{3}{*}{ Family } & \multicolumn{2}{|c|}{ Parental values } & \multirow{2}{*}{\multicolumn{2}{|c|}{$\begin{array}{c}\text { Offspring } \\
\text { mean (range) }\end{array}$}} \\
\hline & \multirow{2}{*}{$\begin{array}{l}\text { M, P } \\
1998\end{array}$} & \multirow{2}{*}{$\begin{array}{c}\text { M, P } \\
1999\end{array}$} & & \\
\hline & & & 1998 & 1999 \\
\hline 1 & $40.9,22.1$ & $52.1,26.2$ & $\begin{array}{c}28.9 \\
(23.0-39.4)\end{array}$ & $\begin{array}{c}30.3 \\
(22.9-39.4)\end{array}$ \\
\hline 2 & $36.0,39.6$ & $46.7,30.1$ & $\begin{array}{c}31.9 \\
(23.9-46.9)\end{array}$ & $\begin{array}{c}33.5 \\
(25.6-53.8)\end{array}$ \\
\hline 3 & $36.0,29.5$ & $46.7,29.1$ & $\begin{array}{c}34.3 \\
(24.3-46.9)\end{array}$ & $\begin{array}{c}35.8 \\
(25.3-46.7)\end{array}$ \\
\hline 4 & $34.8,28.1$ & $40.6,26.2$ & $\begin{array}{c}32.3 \\
(27.5-41.3)\end{array}$ & $\begin{array}{c}28.3 \\
(22.9-36.4)\end{array}$ \\
\hline 5 & $34.8,32.0$ & $40.6,30.6$ & $\begin{array}{c}36.0 \\
(28.7-45.1)\end{array}$ & $\begin{array}{c}35.5 \\
(30.5-42.6)\end{array}$ \\
\hline 6 & $24.3,21.4$ & $27.8,23.0$ & $\begin{array}{c}29.2 \\
(21.0-39.8)\end{array}$ & $\begin{array}{c}28.5 \\
(21.7-39.1)\end{array}$ \\
\hline 7 & $24.3,28.7$ & $27.8,22.0$ & $\begin{array}{c}31.2 \\
(20.0-38.7)\end{array}$ & $\begin{array}{c}31.0 \\
(21.3-41.6)\end{array}$ \\
\hline 8 & $27.7,22.1$ & $27.1,26.2$ & $\begin{array}{c}26.6 \\
(11.6-34.7)\end{array}$ & $\begin{array}{c}26.6 \\
(11.9-36.0)\end{array}$ \\
\hline 9 & $32.0,56.5$ & $30.8,48.8$ & $\begin{array}{c}33.8 \\
(25.0-43.0)\end{array}$ & $\begin{array}{c}34.7 \\
(26.1-40.6)\end{array}$ \\
\hline 10 & $30.1,39.2$ & $24.9,37.6$ & $\begin{array}{c}30.2 \\
(24.8-41.9)\end{array}$ & $\begin{array}{c}30.7 \\
(26.4-37.5)\end{array}$ \\
\hline 11 & $35.0,26.2$ & $25.4,29.0$ & $\begin{array}{c}30.3 \\
(21.8-46.5)\end{array}$ & $\begin{array}{c}30.1 \\
(21.6-39.1)\end{array}$ \\
\hline 12 & $21.0,34.4$ & $18.9,44.4$ & $\begin{array}{c}28.3 \\
(24.2-35.1)\end{array}$ & $\begin{array}{c}31.1 \\
(26.6-39.1)\end{array}$ \\
\hline 13 & $21.0,41.5$ & $18.9,39.3$ & $\begin{array}{c}31.9 \\
(21.5-39.5)\end{array}$ & $\begin{array}{c}32.5 \\
(22.6-42.0)\end{array}$ \\
\hline 14 & $35.0,23.7$ & $25.4,29.9$ & $\begin{array}{c}31.6 \\
(23.9-36.5)\end{array}$ & $\begin{array}{c}33.0 \\
(25.5-42.3)\end{array}$ \\
\hline 15 & $30.0,23.7$ & $32.3,29.9$ & $\begin{array}{c}27.5 \\
(20.3-50.2)\end{array}$ & $\begin{array}{c}29.5 \\
(23.6-38.9)\end{array}$ \\
\hline 16 & $30.0,28.9$ & $32.3,29.7$ & $\begin{array}{c}30.0 \\
(20.9-36.1)\end{array}$ & $\begin{array}{c}37.2 \\
(32.3-43.6)\end{array}$ \\
\hline 17 & $53.1,28.9$ & $34.9,29.7$ & $\begin{array}{c}46.0 \\
(31.5-59.6)\end{array}$ & $\begin{array}{c}45.1 \\
(25.2-63.8)\end{array}$ \\
\hline 18 & $53.1,42.8$ & $34.9,34.8$ & $\begin{array}{c}44.4 \\
(28.8-60.5)\end{array}$ & $\begin{array}{c}38.2 \\
(25.9-49.6)\end{array}$ \\
\hline 19 & $11.4,21.0$ & $25.9,18.9$ & $\begin{array}{c}25.5 \\
(10.9-35.1)\end{array}$ & $\begin{array}{c}28.4 \\
(14.1-38.4)\end{array}$ \\
\hline 20 & $21.5,11.4$ & $22.9,25.9$ & $\begin{array}{c}32.4 \\
(22.0-46.2)\end{array}$ & $\begin{array}{c}31.6 \\
(24.6-39.5)\end{array}$ \\
\hline SE & $1.5^{\mathrm{z}}$ & $1.4^{\mathrm{z}}$ & $2.0^{\mathrm{y}}$ & $1.9^{\mathrm{y}}$ \\
\hline
\end{tabular}

${ }_{\mathrm{Z}}^{\mathrm{SE}}$ based on parental and offspring genotype means for individual years.

${ }^{\mathrm{y}_{\mathrm{SE}}}$ based on family means for individual years. 
years, although there were rank changes among the families, and among the offspring within families, between years. This is in contrast to ACY, in which the overall mean performance differed between years, but crosses maintained their relative ranking. While among-family variation accounted for a substantial amount of total variation for each of the three traits (24\% for AA, $27 \%$ for $\mathrm{TPH}$, and $25 \%$ for ACY), within-family variation accounted for a considerably greater proportion of total variation: $38 \%$ for AA, $48 \%$ for $\mathrm{TPH}$, and $56 \%$ for ACY. Yearly variation, interactions, and variation among extracts were relatively small contributors to total variation.
Positive transgressive segregants were identified as those offspring whose 2-year mean exceeded the higher parental mean by at least two SDs based on the pooled error of all genotypes. For AA, one transgressive segregant was identified in each of three families, three in each of two families, four in one family, and five in one family. For TPH, one transgressive segregant was identified in each of four families; two in each of three families; and three in each of five families. For ACY, one transgressive segregant was identified in each of three families, two in each of two families, three in each of three families, and four in each of four families. With the exception of two transgressive segregants

Table 3. Total phenolic content (mg chlorogenic acid equivalents $/ 100 \mathrm{~g}$ fresh fruit) for maternal (M) and paternal (P) parents with mean and range among 10 offspring, in 20 blueberry (Vaccinium sp.) families (listed by number as indicated in Table 1) in 1998 and 1999.

\begin{tabular}{|c|c|c|c|c|}
\hline \multirow[b]{3}{*}{ Family } & \multicolumn{2}{|c|}{ Parental values } & \multirow{2}{*}{\multicolumn{2}{|c|}{$\begin{array}{c}\text { Offspring } \\
\text { mean (range) }\end{array}$}} \\
\hline & \multirow{2}{*}{$\begin{array}{l}\text { M, P } \\
1998\end{array}$} & \multirow{2}{*}{$\begin{array}{l}\mathrm{M}, \mathrm{P} \\
1999\end{array}$} & & \\
\hline & & & 1998 & 1999 \\
\hline \multirow[t]{2}{*}{1} & 592,432 & 739,473 & 476 & 494 \\
\hline & & & $(351-652)$ & $(365-662)$ \\
\hline \multirow[t]{2}{*}{2} & 496,576 & 662,526 & 516 & 527 \\
\hline & & & $(421-727)$ & $(439-791)$ \\
\hline \multirow[t]{2}{*}{3} & 496,510 & 662,556 & 504 & 538 \\
\hline & & & $(393-592)$ & $(422-693)$ \\
\hline \multirow[t]{2}{*}{4} & 562,435 & 643,388 & 508 & 458 \\
\hline & & & $(440-614)$ & $(354-567)$ \\
\hline \multirow[t]{2}{*}{5} & 562,532 & 643,463 & 570 & 580 \\
\hline & & & $(446-712)$ & $(486-694)$ \\
\hline \multirow[t]{2}{*}{6} & 426,471 & 482,391 & 479 & 496 \\
\hline & & & $(401-629)$ & $(382-634)$ \\
\hline \multirow[t]{2}{*}{7} & 426,478 & 482,471 & 528 & 546 \\
\hline & & & $(408-686)$ & (391-703) \\
\hline \multirow[t]{2}{*}{8} & 483,432 & 448,473 & 444 & 452 \\
\hline & & & $(167-566)$ & $(166-611)$ \\
\hline \multirow[t]{2}{*}{9} & 521,851 & 627,662 & 591 & 628 \\
\hline & & & $(517-688)$ & $(503-749)$ \\
\hline \multirow[t]{2}{*}{10} & 499,631 & 466,574 & 498 & 497 \\
\hline & & & $(430-578)$ & $(380-593)$ \\
\hline \multirow[t]{2}{*}{11} & 507,406 & 498,528 & 500 & 517 \\
\hline & & & $(421-701)$ & $(401-652)$ \\
\hline \multirow[t]{2}{*}{12} & 436,512 & 379,588 & 487 & 501 \\
\hline & & & $(424-595)$ & $(431-593)$ \\
\hline \multirow[t]{2}{*}{13} & 436,703 & 379,781 & 534 & 558 \\
\hline & & & $(387-650)$ & (394-690) \\
\hline \multirow[t]{2}{*}{14} & 507,397 & 498,452 & 535 & 550 \\
\hline & & & $(420-669)$ & $(474-653)$ \\
\hline \multirow[t]{2}{*}{15} & 589,397 & 553,452 & 469 & 505 \\
\hline & & & $(353-725)$ & $(378-721)$ \\
\hline \multirow[t]{2}{*}{16} & 589,472 & 553,495 & 511 & 598 \\
\hline & & & $(413-598)$ & $(473-655)$ \\
\hline \multirow[t]{2}{*}{17} & 760,472 & 576,495 & 730 & 713 \\
\hline & & & $(532-970)$ & $(439-1176)$ \\
\hline \multirow[t]{2}{*}{18} & 760,599 & 576,528 & 663 & 616 \\
\hline & & & $(489-840)$ & $(468-778)$ \\
\hline \multirow[t]{2}{*}{19} & 373,436 & 373,379 & 449 & 443 \\
\hline & & & $(209-598)$ & $(198-613)$ \\
\hline \multirow[t]{2}{*}{20} & 476,373 & 428,373 & 565 & 537 \\
\hline & & & $(433-815)$ & $(455-713)$ \\
\hline SE & $12^{z}$ & $11^{\mathrm{z}}$ & $28^{y}$ & $31^{\mathrm{y}}$ \\
\hline
\end{tabular}


Table 4. Anthocyanin content (mg cyanidin 3-glucoside equivalents/100 g fresh fruit) for maternal (M) and paternal (P) parents with mean and range among 10 offspring, in 20 blueberry (Vaccinium sp.) families (listed by number as indicated in Table 1) in 1998 and 1999.

\begin{tabular}{|c|c|c|c|c|}
\hline \multirow[b]{3}{*}{ Family } & \multicolumn{2}{|c|}{ Parental values } & \multirow{2}{*}{\multicolumn{2}{|c|}{$\begin{array}{c}\text { Offspring } \\
\text { mean (range) }\end{array}$}} \\
\hline & \multirow{2}{*}{$\begin{array}{l}\text { M, P } \\
1998\end{array}$} & \multirow{2}{*}{$\begin{array}{l}\text { M, P } \\
1999\end{array}$} & & \\
\hline & & & 1998 & 1999 \\
\hline 1 & 182,172 & 228,181 & $\begin{array}{c}183 \\
(107-264)\end{array}$ & $\begin{array}{c}191 \\
(118-275)\end{array}$ \\
\hline 2 & 168,236 & 204,210 & $\begin{array}{c}193 \\
(140-266)\end{array}$ & $\begin{array}{c}207 \\
(150-308)\end{array}$ \\
\hline 3 & 168,214 & 204,220 & $\begin{array}{c}189 \\
(147-227)\end{array}$ & $\begin{array}{c}196 \\
(144-229)\end{array}$ \\
\hline 4 & 205,142 & 216,135 & $\begin{array}{c}186 \\
(154-221)\end{array}$ & $\begin{array}{c}181 \\
(148-230)\end{array}$ \\
\hline 5 & 205,203 & 216,177 & $\begin{array}{c}209 \\
(148-258)\end{array}$ & $\begin{array}{c}241 \\
(189-317)\end{array}$ \\
\hline 6 & 199,164 & 223,152 & $\begin{array}{c}198 \\
(166-246)\end{array}$ & $\begin{array}{c}208 \\
(163-273)\end{array}$ \\
\hline 7 & 199,198 & 223,199 & $\begin{array}{c}225 \\
(143-303)\end{array}$ & $\begin{array}{c}248 \\
(156-351)\end{array}$ \\
\hline 8 & 178,172 & 183,181 & $\begin{array}{c}177 \\
(3-238)\end{array}$ & $\begin{array}{c}186 \\
(2-279)\end{array}$ \\
\hline 9 & 227,421 & 253,435 & $\begin{array}{c}271 \\
(210-317)\end{array}$ & $\begin{array}{c}300 \\
(230-367)\end{array}$ \\
\hline 10 & 167,250 & 164,231 & $\begin{array}{c}184 \\
(140-223)\end{array}$ & $\begin{array}{c}201 \\
(130-287)\end{array}$ \\
\hline 11 & 178,140 & 209,173 & $\begin{array}{c}188 \\
(144-231)\end{array}$ & $\begin{array}{c}203 \\
(164-266)\end{array}$ \\
\hline 12 & 164,194 & 160,225 & $\begin{array}{c}197 \\
(158-270)\end{array}$ & $\begin{array}{c}202 \\
(166-232)\end{array}$ \\
\hline 13 & 164,326 & 160,355 & $\begin{array}{c}223 \\
(165-279)\end{array}$ & $\begin{array}{c}243 \\
(170-298)\end{array}$ \\
\hline 14 & 178,141 & 209,197 & $\begin{array}{c}200 \\
(158-230)\end{array}$ & $\begin{array}{c}234 \\
(198-286)\end{array}$ \\
\hline 15 & 215,141 & 212,197 & $\begin{array}{c}184 \\
(109-285)\end{array}$ & $\begin{array}{c}213 \\
(149-332)\end{array}$ \\
\hline 16 & 215,160 & 212,169 & $\begin{array}{c}211 \\
(160-248)\end{array}$ & $\begin{array}{c}232 \\
(198-262)\end{array}$ \\
\hline 17 & 269,160 & 229,169 & $\begin{array}{c}272 \\
(208-420)\end{array}$ & $\begin{array}{c}282 \\
(167-492)\end{array}$ \\
\hline 18 & 269,197 & 229,180 & $\begin{array}{c}219 \\
(148-274)\end{array}$ & $\begin{array}{c}228 \\
(164-327)\end{array}$ \\
\hline 19 & 110,164 & 118,160 & $\begin{array}{c}148 \\
(36-226)\end{array}$ & $\begin{array}{c}149 \\
(23-240)\end{array}$ \\
\hline 20 & 214,110 & 189,118 & $\begin{array}{c}237 \\
(154-349)\end{array}$ & $\begin{array}{c}236 \\
(181-327)\end{array}$ \\
\hline SE & $5^{z}$ & $5^{z}$ & $14^{y}$ & $16^{\mathrm{y}}$ \\
\hline
\end{tabular}

${ }_{\mathrm{SE}}^{\mathrm{z}}$ based on parental and offspring genotype means for individual years.

$\mathrm{y}_{\mathrm{SE}}$ based on family means for individual years.

Table 5. Expected mean squares for sources of variation included in ANOVA for family antioxidant activity, total phenolic content, and anthocyanin content shown in Table 6, based on duplicate determinations in each of three extractions of fruit from 10 offspring from 20 blueberry families measured in 1998 and 1999.

\begin{tabular}{|c|c|}
\hline Variance component & Expected mean squares \\
\hline Family & $\sigma_{\text {error }}^{2}+2 \sigma_{\text {extract (offspring/family) } \times \text { year }}^{2}+6 \sigma_{\text {offspring (family) } \times \text { year }}^{2}+12 \sigma_{\text {offspring (family) }}^{2}+60 \sigma_{\text {family } \times \text { year }}^{2}+120 \sigma_{\text {family }}^{2}$ \\
\hline Offspring/family & $\sigma_{\text {error }}^{2}+2 \sigma_{\text {extract (offspring/family) } \times \text { year }}^{2}+6 \sigma_{\text {offspring (family) } \times \text { year }}^{2}+12 \sigma_{\text {offspring (family) }}^{2}$ \\
\hline Year & $\sigma_{\text {error }}^{2}+2 \sigma_{\text {extract (offspring/family) } \times \text { year }}^{2}+6 \sigma_{\text {offspring (family) } \times \text { year }}^{2}+60 \sigma_{\text {family } \times \text { year }}^{2}+1200 \sigma_{\text {year }}^{2}$ \\
\hline Family $\times$ year & 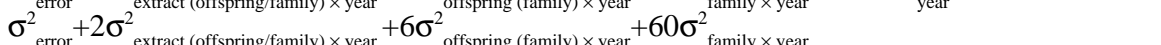 \\
\hline Offspring/family $\times$ year & $\sigma_{\text {error }}^{2}+2 \sigma_{\text {extract (offspring/family) } \times \text { vear }}^{2}+6 \sigma_{\text {offspring (family) } \times \text { year }}^{2}$ \\
\hline Extract (offspring/family) $\times$ year & $\sigma_{\text {error }}^{2}+2 \sigma_{\text {extract (offspring/family) } \times \text { year }}^{2}$ \\
\hline Error & $\sigma_{\text {error }}^{2}$ \\
\hline
\end{tabular}


Table 6. ANOVA for antioxidant activity (AA), total phenolic content (TPH), and anthocyanin content (ACY) evaluated in 1998 and 1999 in 10 offspring from 20 blueberry (Vaccinium sp.) families (top), and proportion of total variance accounted for by each component of variance (bottom) based on the expected mean squares shown in Table 5.

\begin{tabular}{|c|c|c|c|c|c|c|c|}
\hline \multirow[b]{2}{*}{ Source } & \multirow[b]{2}{*}{$\mathrm{df}$} & \multicolumn{2}{|c|}{ AA } & \multicolumn{2}{|c|}{ TPH } & \multicolumn{2}{|c|}{$\mathrm{ACY}$} \\
\hline & & $\begin{array}{l}\text { Mean } \\
\text { square }\end{array}$ & $\mathrm{F}$ & $\begin{array}{l}\text { Mean } \\
\text { square }\end{array}$ & $\mathrm{F}$ & $\begin{array}{l}\text { Mean } \\
\text { square }\end{array}$ & $\mathrm{F}$ \\
\hline Family & 19 & 2509.5 & $4.82^{* * * *}$ & 522510 & $5.03^{* * * *}$ & 124250 & $4.81^{* * *}$ \\
\hline Offspring/family & 180 & 390.1 & $4.80^{* * * *}$ & 90010 & $6.35^{* * *}$ & 24467 & $10.91^{* * * *}$ \\
\hline Year & 1 & 138.3 & $0.43^{\mathrm{Ns}}$ & 58464 & $2.09^{\mathrm{NS}}$ & 122300 & $33.75^{* * * *}$ \\
\hline Family $\times$ year & 19 & 211.8 & $2.61^{* * * *}$ & 27972 & $1.97 *$ & 3624 & $1.62^{\mathrm{NS}}$ \\
\hline Offspring/family $\times$ year & 180 & 81.2 & $3.43^{* * *}$ & 14167 & $7.45^{* * * *}$ & 2242 & $5.43^{* * *}$ \\
\hline Extract (offspring/family) $\times$ year & 800 & 23.7 & $4.86^{* * * *}$ & 1901 & $145.61^{* * * *}$ & 413 & $99.42^{* * * *}$ \\
\hline Error & 1200 & 4.9 & & 13 & & 4 & \\
\hline
\end{tabular}

Percentage of total variance

\begin{tabular}{lrrr}
\cline { 2 - 4 } Variance component & AA & TPH & ACY \\
\hline Family & 24.2 & 27.3 & 24.8 \\
Offspring/family & 37.7 & 48.0 & 56.0 \\
Year & 0.0 & 0.2 & 3.0 \\
Family $\times$ year & 3.2 & 1.8 & 0.7 \\
Offspring/family $\times$ year & 14.0 & 15.5 & 9.2 \\
Extract (offspring/family) $\times$ year & 13.8 & 7.1 & 6.2 \\
Error & 7.1 & 0.1 & 0.1
\end{tabular}

$\mathrm{Ns}^{*},{ }^{* * *}$ Nonsignificant, or significant at $P \leq 0.05$ or 0.001 , respectively.

in separate families, the offspring transgressive for AA were among those identified as transgressive for either TPH or ACY.

The narrow-sense heritability estimates and SEs for AA were $h^{2}=0.46 \pm 0.11(P \leq 0.001)$ in $1998, h^{2}=0.34 \pm 0.18(P=0.073)$ in 1999 , and $h^{2}=0.43 \pm 0.09(P \leq 0.001)$ for combined years. The range in midparent AA values decreased from 1998 to 1999, particularly among those representing the higher AA values, contributing to the increased SE in 1999.

For TPH, the individual heritability estimates differed substantially between $1998\left(h^{2}=0.62 \pm 0.15, P \leq 0.001\right)$ and $1999\left(h^{2}=0.34\right.$ $\pm 0.15, P \leq 0.05)$. The combined year estimate, $h^{2}=0.46 \pm 0.11(P$ $\leq 0.001$ ), was similar to that for AA. Two crosses that had high midparent TPH values in 1998 were decreased in 1999, and the decreased range in midparent values may explain the relatively higher SE for the heritability estimate in 1999. For ACY, individual and combined year heritability estimates were very similar $\left(h^{2}=0.53\right.$ $\pm 0.13(P \leq 0.001)$ for $1998, h^{2}=0.57 \pm 0.15(P \leq 0.001)$ for 1999 , and $h^{2}=0.56 \pm 0.10(P \leq 0.001)$ for combined years $)$.
The ANOVAs for AA, TPH, and ACY based on offspring genotypes and years, and on family means and years from which repeatability estimates were calculated are presented in Table 7. Repeatability between years was high for all traits on both a genotype mean basis and a family mean basis.

\section{Discussion}

Narrow-sense heritability estimates allow breeders to predict the likelihood of success in changing population traits through cycles of breeding and selection by indicating the degree to which individuals' phenotypes reflect their breeding values. In breeding for a trait such as AA, which in blueberry appears to be due to numerous phenolic compounds including anthocyanins, phenolic acids, and other flavonoids, the influence of many genes on trait expression would be expected. The narrow-sense heritability estimate of 0.43 for AA, based on offspring-midparent regression over 2 years, is moderate and suggests reasonable progress could

Table 7. ANOVA and repeatability for antioxidant activity (AA), total phenolic content (TPH), and anthocyanin content (ACY) for combined years, based on 200 offspring genotype means [10 from each of 20 blueberry (Vaccinium sp.) crosses] (top) and based on family means for the same 20 blueberry crosses (bottom).

\begin{tabular}{|c|c|c|c|c|c|}
\hline Source & df & $\begin{array}{c}\text { AA } \\
\text { mean square }\end{array}$ & $\begin{array}{c}\text { TPH } \\
\text { mean square }\end{array}$ & $\begin{array}{c}\text { ACY } \\
\text { mean square }\end{array}$ & $\begin{array}{l}\text { Expected } \\
\text { mean square }\end{array}$ \\
\hline Genotype & 199 & 98.7 & 21884 & 5665 & $\sigma_{\text {genotype } \times \text { year }}^{2}+2 \sigma_{\text {genoty }}^{2}$ \\
\hline Year & 1 & 23.1 & 9745 & 20411 & $\sigma^{2_{\text {genotype } x \text { year }}^{\text {genotype }}+20 \sigma^{\text {genoty }}}$ \\
\hline Genotype $\times$ year & 199 & 15.6 & 2581 & 395 & $\sigma_{\text {genotype } \times \text { year }}^{2^{\text {genotype }}}$ \\
\hline Repeatability $^{z}$ & & 0.84 & 0.88 & 0.93 & \\
\hline Family & 19 & 41.8 & 8708 & 2071 & $\sigma_{\text {family }}^{2}+2 \sigma_{\text {family }}^{2}$ \\
\hline Year & 1 & 2.3 & 974 & 2038 & $\sigma_{\text {family } \times \text { year }}^{\text {family }}+20 \sigma_{\text {year }}^{2}$ \\
\hline Family $\times$ year & 19 & 3.5 & 466 & 60 & $\sigma_{\text {family } \times \text { year }}^{\text {famly }}$ \\
\hline Repeatability ${ }^{\mathrm{y}}$ & & 0.92 & 0.95 & 0.97 & \\
\hline
\end{tabular}

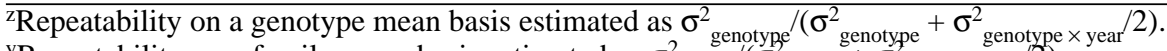

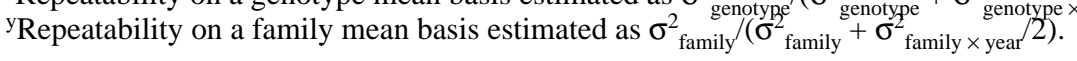


be made in increasing AA in our population. Since AA is likely to be only one of a number of traits on which selection is based, early stages in a breeding program using multistage selection might continue to be based on other, more highly heritable traits. The narrow-sense heritability estimate for TPH (0.46) was also moderate and similar to that for AA. Furthermore, the correlation between TPH and AA was high in this study $(r=0.91)$. This is similar to the correlations obtained in studies of blueberry by Connor (2001) and Prior et al. (1998), and slightly higher than that obtained by Ehlenfeldt and Prior (2001) $(r=0.76)$. The heritability estimate for ACY $\left(h^{2}=0.56\right)$ was slightly higher, but the correlation between ACY and AA in this study $(r=0.70)$ and in previous studies $(r=0.73$, Connor, 2001; $r=0.77$, Prior et al., 1998; $r=0.57$, Ehlenfeldt and Prior, 2001), is somewhat lower than that of AA with TPH. This may make ACY less suitable than TPH to use for indirect selection for AA. The relatively narrower range of within-family AA values as compared to $\mathrm{ACY}$ values also suggests that the greater variation in $\mathrm{ACY}$ is not necessarily reflected as greater variation in AA. The proportion of variance due to experimental error was very small for TPH, which indicated its usefulness as a secondary character for indirect selection for AA. Selecting for higher AA based on TPH could be problematic if the phenolic compounds contributing to AA were sensorially objectionable. Anthocyanins appear to account for considerable AA, but in our germplasm did not contribute adversely to the taste and aroma. Information regarding the contribution of other blueberry phenolics to their sensory qualities is not currently available.

The heritability estimates in the present study have several limitations, including possible upward bias due to environmental covariance, as the parents and the offspring were grown at the same location. Additionally, the regression coefficient, $b$, estimates narrow-sense heritability, $h^{2}$, only if disomic inheritance and normal meiosis are assumed so that $\operatorname{cov}(\mathrm{O}, \mathrm{MP})$ estimates 0.5 $\sigma^{2}$. Cytogenetic studies have shown predominantly, but not exclusively, bivalent pairing of chromosomes in tetraploid blueberry (Jelenkovic and Harrington, 1971; Jelenkovic and Hough, 1970). However, isozyme studies based on segregation at four loci suggest tetrasomic inheritance in tetraploid V. corymbosum (Krebs and Hancock, 1989). If inheritance in blueberry is strictly tetrasomic, then $\operatorname{cov}(\mathrm{O}, \mathrm{MP})$ estimates $0.5 \sigma_{\mathrm{A}}^{2}+0.17 \sigma_{\mathrm{D}}^{2}$, so that estimates of narrow-sense heritability are biased upward. Lastly, since fruit were harvested from single plants, the estimates apply to single-plant selection; heritability could be higher if data were obtained from multiple-plant plots or replicated plots.

The high repeatability between years for AA, TPH, and ACY estimated on a family mean basis and on a genotype mean basis suggests that, within one location, the values obtained in 1 year for these variables should be reliable indicators of values obtained in other years. Repeatability on a genotype mean basis gives a good approximation of broad-sense heritability, which is relevant to selection among plants in clonally propagated crops such as blueberry. However, as the full ANOVA for family data and combined years suggest, rank or scale changes among and within families between years may be observed.

Estimates of the components of variance for all three traits revealed that a high proportion of the total variance was within crosses and among crosses, and a small proportion was attributable to year effects, family $\times$ year interactions, offspring $\times$ year interactions, and variation among extractions. Transgressive segregants for each of the traits were identified among the offspring. For AA, $9 \%$ of the offspring, occurring in seven of the 20 families, were transgressive segregants for AA. These data suggest selec- tion among a larger number of offspring from each cross, at the expense of sampling some potential crosses, may be the strategy that most efficiently uses resources in a breeding program.

\section{Literature Cited}

Barclay, L.R.C., S.J. Locke, J.M. MacNeil, J. VanKessel, G.W. Burton, and K.U. Ingold 1984. Autooxidation of micelles and model membranes. Quantitative kinetic measurements can be made by using either water-soluble or lipid-soluble initiators with watersoluble or lipid-soluble chain-breaking antioxidants. J. Amer. Chem. Soc. 106:24792481.

Connor, A.M. 2001. Variation and heritability of antioxidant activity and its relationship to anthocyanin content and total phenolic content in blueberry (Vaccinium subspecies Cyanococcus). PhD diss., Univ. of Minnesota, St. Paul.

Coseteng, M.Y. and C.Y. Lee. 1987. Changes in apple polyphenoloxidase and polyphenol concentration in relation to degree of browning. J. Food Sci. 52:985-989. Ehlenfeldt, M. and R.L. Prior. 2001. Oxygen radical absorbance capacity (ORAC) and phenolic and anthocyanin concentrations in fruit and leaf tissues of highbush blueberry. J. Agr. Food Chem. 49:2222-2227.

Falconer, D.S. and T.F.C. Mackay. 1996. Introduction to quantitative genetics. $4^{\text {th }}$ ed. Prentice Hall, New York.

Fuhrman, B., A. Lavy, and M. Aviram. 1995. Consumption of red wine with meals reduces the susceptibility of human plasma and low-density lipoprotein to lipid peroxidation. Amer. J. Clinical Nutr. 61:549-554.

Gao, L. and G. Mazza. 1994. Quantitation and distribution of simple and acylated anthocyanins and other phenolics in blueberries. J. Food Sci. 59:1057-1059.

Harborne, J.B. 1967. Comparative biochemistry of the flavonoids. Academic Press, New York.

Hertog, M.G.L., E.J.M. Feskens, P.C.H. Hollman, M.B. Katan, and D. Kromhout. 1993. Dietary antioxidant flavonoids and risk of coronary heart disease: The Zutphen Elderly Study. Lancet 342:1007-1011.

Hertog, M.G.L., E.J.M. Feskens, and D. Kromhout. 1997. Antioxidant flavonols and coronary heart disease risk. Lancet 349:699.

Jelenkovic, G. and E. Harrington. 1971. Non-random chromosome associations at diplotene and diakinesis and diakinesis in a tetraploid clone of Vaccinium australe Small. Can. J. Genet. Cytol. 13:270-276.

Jelenkovic, G. and L.F. Hough. 1970. Chromosome associations in the first meiotic division in three tetraploid clones of Vaccinium corymbosum L. Can. J. Genet. Cytol. 12:316-324.

Joshipura, K.J., A. Ascherio, J.E. Manson, M.J. Stampfer, E.B. Rimm, F.E. Speizer, C.H. Hennekens, D Spiegelman, and W.C. Willett. 1999. Fruit and vegetable intake in relation to risk of ischemic stroke. JAMA 282:1233-1239.

Kalt, W., C.F. Forney, A. Martin, and R.L. Prior. 1999. Antioxidant capacity, vitamin C, phenolics, and anthocyanins after fresh storage of small fruit. J. Agr. Food Chem. 47:4638-4644

Keli, S.O., M.G.L. Hertog, E.J.M. Heskens, and D. Kromhout. 1996. Dietary flavonoids, antioxidant vitamins and incidence of stroke. Arch. Intern. Med. 156:637642.

Knekt, P., R. Järvinen, A. Reunanen, and J. Maatella. 1996. Flavonoid intake and coronary mortality in Finland: A cohort study. Brit. Med. J. 312:478-481.

Knekt, P., R. Järvinen, R. Seppänen, M. Heliövaara, L. Teppo, E. Pukkala, and A. Aromaa. 1997. Dietary flavonoids and the risk of lung cancer and other malignant neoplasms. Amer. J. Epidemiol. 146:223-230.

Krebs, S.L. and J.F. Hancock. 1989. Tetrasomic inheritance of isoenzyme markers in the highbush blueberry, Vaccinium corymbosum L. Heredity 63:11-18.

Lee, H-S., D.W. Shoeman, and A.S. Csallany. 1992. Urinary response to in vivo lipid peroxidation induced by vitamin E deficiency. Lipids 27:125-128.

Liu, S., J.E. Manson, I-M. Lee, S.R. Cole, C.H. Hennekens, W.C. Willett, and J.E. Buring. 2000. Fruit and vegetable intake and risk of cardiovascular disease in the Women's Health Study. Amer. J. Clinical Nutr. 72:922-928.

Ness, A.R. and J.W. Powles. 1997. Fruit and vegetables, and cardiovascular disease: A review. Intl. J. Epidemiol. 26:1-13.

Prior, R.L., G. Cao, A. Martin, E. Sofic, J. McEwen, C. O’Brien, N. Lischner, M. Ehlenfeldt, W. Kalt, G. Krewer, and C.M. Mainland. 1998. Antioxidant capacity as influenced by total phenolic and anthocyanin content, maturity, and variety of Vaccinium species. J. Agr. Food Chem. 46:2686-2693.

Satterthwaite, F.E. 1946. An approximate distribution of estimates of variance components. Biometrics 2:110-114.

Steinmetz, K.A. and J.D. Potter. 1996. Vegetable, fruit, and cancer prevention: A review. J. Amer. Diet. Assn. 96:1027-1039.

Zhang, S.M.M., D.J. Hunter, B.A. Rosner, E.L. Giovannucci, G.A. Colditz, F.E. Speizer, and W.C. Willett. 2000. Intakes of fruit, vegetables, and related nutrients and the risk of non-Hodgkin's lymphoma among women. Cancer Epidemiol. Biomark. Prevent. 9:477-485. 